\title{
The role of silicon on C:N:P stoichiometry and yield of sugar beet under ammonium toxicity
}

\section{Dilier Olivera Viciedo ( $\nabla$ dilierolvi@gmail.com )}

Laboratory of Plant Nutrition, Soils and Fertilizers Sector, Department of Agricultural Production

Sciences, São Paulo State University “Júlio de Mesquita Filho” (UNESP), Jaboticabal, São Paulo, Brazil https://orcid.org/0000-0002-7975-9508

\section{Renato de Mello Prado}

Laboratory of Plant Nutrition, Soils and Fertilizers Sector, Department of Agricultural Production Sciences, São Paulo State University “Júlio de Mesquita Filho” (UNESP), Jaboticabal, São Paulo, Brazil https://orcid.org/0000-0003-1998-6343

\section{Kolima Peña}

Laboratory of Plant Nutrition, Soils and Fertilizers Sector, Department of Agricultural Production Sciences, São Paulo State University “Júlio de Mesquita Filho" (UNESP), Jaboticabal, São Paulo, Brazil https://orcid.org/0000-0003-4883-4293

\section{Alexander Calero-Hurtado}

Laboratory of Plant Nutrition, Soils and Fertilizers Sector, Department of Agricultural Production Sciences, São Paulo State University “Júlio de Mesquita Filho” (UNESP), Jaboticabal, São Paulo, Brazil https://orcid.org/0000-0001-6536-2908

\section{Marisa de Cássia Piccolo}

University of São Paulo, Center of Nuclear Energy in Agriculture, Piracicaba, São Paulo, Brazil https://orcid.org/0000-0003-2163-5630

\section{Mariana Bomfim Soares}

Laboratory of Plant Nutrition, Soils and Fertilizers Sector, Department of Agricultural Production Sciences, São Paulo State University “Júlio de Mesquita Filho” (UNESP), Jaboticabal, São Paulo, Brazil https://orcid.org/0000-0001-8705-4578

\section{Rodolfo Toledo Lizcano}

1Universidad de Granada. International Graduate School, University of Granada https://orcid.org/00000003-2797-0237

\section{Research Article}

Keywords: Abiotic stress, Beta vulgaris, nitrogen, plant growth, hydroponic cultivation

Posted Date: February 24th, 2022 
DOI: https://doi.org/10.21203/rs.3.rs-1393734/v1

License: (c) (1) This work is licensed under a Creative Commons Attribution 4.0 International License. Read Full License 


\section{Abstract}

Most plants develop severe toxicity symptoms when grown on $\mathrm{NH}_{4}{ }^{+}$as the sole nitrogen source, resulting in physiological and nutritional disturbances that slow vegetable growth. In this scenario of $\mathrm{NH}_{4}{ }^{+}$stress, it is important to use strategies to mitigate this toxicity, and the use of silicon ( $\mathrm{Si}$ ) has promoted promising results. However, underlying studies on the effects of ammonia toxicity on C:N:P stoichiometric homeostasis and the role of $\mathrm{Si}$ in these stoichiometric ratios are lacking. In this study, we investigated the effects of different $\mathrm{NH}_{4}{ }^{+}$concentration on the $\mathrm{C}: \mathrm{N}: \mathrm{P}$ stoichiometry and yield of sugar beet grown under hydroponic conditions, and examined whether the application of Si can alleviate the detrimental effects caused by toxic levels of $\mathrm{NH}_{4}{ }^{+}$. We conducted a hydroponic experiment to evaluate the effects of five concentrations of ammonium $\left(1,7.5,15,22.5\right.$, and $\left.30 \mathrm{mmol} \mathrm{L}^{-1}\right)$ on $\mathrm{C}: \mathrm{N}: \mathrm{P}$ stoichiometry and yield of sugar beet $\mathrm{cv}$. Early Wonder in the absence and presence $\left(2 \mathrm{mmol} \mathrm{L}^{-1}\right)$ of $\mathrm{Si}$. The experimental design was a randomized block design based on a $5 \times 2$ factorial scheme with four replicates. Our results indicate that in presence of $\mathrm{Si}$ both $[\mathrm{N}]$ and $[\mathrm{P}]$ in shoots and roots increased significantly and reaching its highest value at $15 \mathrm{mmol} \mathrm{L}^{-1}$ of $\mathrm{NH}_{4}^{+}$in the nutrient solution, while shoot [C] remained stable, in roots increased with $\mathrm{NH}_{4}{ }^{+}$concentrations of 22.5 and $30 \mathrm{mmol} \mathrm{L}^{-1}$, respectively. In addition, shoot and root [Si] increased as higher levels of $\mathrm{NH}_{4}{ }^{+}$in the nutrient solution. Our findings showed that homeostatic instability under highest levels of $\mathrm{NH}_{4}{ }^{+}$, especially in the plants cultivated without $\mathrm{Si}$ in the nutritive solution resulted in decreased shoots and roots dry matter production. In conclusion, both $\mathrm{NH}_{4}{ }^{+}$ concentration or $\mathrm{Si}$ in presence or absence in the nutrient solution can affect $\mathrm{C}: \mathrm{N}: \mathrm{P}$ stoichiometry of sugar beet.

\section{Introduction}

Nitrogen $(\mathrm{N})$ availability is one of the most important factors that determine plant growth in a wide range of environments ${ }^{1,2}$. Ammonium $\left(\mathrm{NH}_{4}{ }^{+}\right)$and nitrate $\left(\mathrm{NO}_{3}{ }^{-}\right)$are the main forms of $\mathrm{N}$ absorbed by plants ${ }^{3}$. Unlike $\mathrm{NO}_{3}{ }^{-}, \mathrm{NH}_{4}{ }^{+}$is directly incorporated into organic compounds without the need for energy-dependent enzymatic reduction. Thus, urea, the worldwide leading nitrogen-fertilizer is converted to ammonium by urease enzymes of soil microorganisms and plants ${ }^{4}$. Consequently, the lower metabolic energy expenditure associated with ammoniacal nutrition can be converted into higher plant growth, and thus higher production ${ }^{1,5}$.

Despite its value as a fertilizer, it is well established that an excess of $\mathrm{NH}_{4}{ }^{+}$can promote the production of reactive oxygen species (ROS), which can cause reductions in cytoplasmic $\mathrm{pH}$, photosynthetic rate, transpiration, and stomatal conductance ${ }^{1}$. Depending on concentration, the exclusive supply of $\mathrm{N}$ as $\mathrm{NH}_{4}{ }^{+}$is harmful to many plants and may cause poor biomass accumulation and ion imbalance ${ }^{1,5,6}$. Toxic levels of $\mathrm{NH}_{4}{ }^{+}$in plant tissues accumulate when the overall rate of the conversion of $\mathrm{NH}_{4}{ }^{+}$into 
amino acids and amides becomes lower than the rate of its uptake and cellular production by amino acid catabolism, $\mathrm{NO}_{3}{ }^{-}$reduction, phenylpropanoid metabolism, and photorespiration ${ }^{7}$.

A known strategy to mitigate nutritional disorders of $\mathrm{NH}_{4}{ }^{+}$is to utilize Silicon (Si) in the nutrient solutions ${ }^{1,5}$. Si is the second most abundant element, after oxygen in the Earth's crust, is absorbed by plants as monosilicic acid $\left(\mathrm{H}_{4} \mathrm{SiO}_{4}\right){ }^{8,9}$, with concentrations varying between 0.1 and $0.6 \mathrm{mM}$, which is about two orders of magnitude higher than the concentrations of phosphorus $(P)^{10}$. The beneficial effects of Si have been observed in various plant species, including Si-accumulating and nonaccumulating species $1,5,11,12$. Seven out of the ten most produced crops in the world (ranked by quantity) are accumulators, see ${ }^{13}$.

All land plants contain $\mathrm{Si}$ in their tissues and although its concentration varies considerably with the species of plant, oscillating between 0.1 and $10 \%$ of its dry weight, its beneficial effects are more notable under environmental stress, caused by both biotic and abiotic sources ${ }^{14-16}$. In plants, a relatively higher quantity of $\mathrm{Si}$ is found than many other essential macronutrients such as calcium, magnesium and phosphorus. For example, grasses even may contain higher levels of Si than any of the other inorganic mineral nutrients ${ }^{11}$. Application of Si positively impact almost all aspects of $\mathrm{N}$ nutrition, i.e., uptake, assimilation, and remobilization $8,17,18$. This beneficial effect of $\mathrm{Si}$ on overall plant performance has been established under low, optimal, and excessive $\mathrm{N}$ supply. In addition to a direct effect on $\mathrm{N}$ metabolism, $\mathrm{Si}$ supply induces changes in carbon (C) and P stoichiometry in shoots ${ }^{19,20}$ and increases nutrient acquisition by roots ${ }^{21,22}$, which in turn can contribute to improving $\mathrm{N}$ utilization within plant tissues.

Sugar beet (Beta vulgaris $L$.) is one of the more important commercial crops, which is around $20 \%$ of the world sugar demand with supplies 36 million $\mathrm{mt}$ of raw sugar yearly ${ }^{23}$. In Brazil, this crops production constitutes one of the main cultivated plants and is the 13th most economically valuable and the estimated planted area in the country is approximately 10,000 ha, with average production rates varying between 20 and $35 \mathrm{t} \mathrm{ha}^{-15,24}$. Nitrogen is the most important element that is applied to sugar beet, because it is difficult finding soils that contain sufficient amounts of this element in any of its available forms. Insufficient supply of $\mathrm{N}$ can reduce plant $\mathrm{N}$ concentration and rate of photosynthesis ${ }^{1}$ and simultaneously reduce plant growth and quality of harvestable materials ${ }^{5}$. The optimal application of $\mathrm{N}$ fertilizers positively impacts production. However, oversupply of $\mathrm{N}$ does not always lead to increased yield, and it might actually result in reduced growth and yield, especially for crops where roots and tubers are harvested ${ }^{25}$.

Elemental stoichiometry has been suggested as a new approach for studying the interaction between plants and soils, as well as the elemental cycling in plant-soil systems in a changing world ${ }^{26}$. The concept of stoichiometric homeostasis refers to the ability of an organism to maintain relatively constant the concentrations or ratios of elements within its tissues under variable environmental conditions ${ }^{27}$. Numerous studies have concluded that carbon (C), N, and phosphorus (P) stoichiometry in plants tends 
to be decoupled under global change ${ }^{28,29}$, but studies involving ammonia toxicity are lacking. Therefore, stoichiometric homeostasis can be used to predict the strategies used by different plant species under biotic and abiotic stresses to cope with limited resources in their surroundings. We hypothesized that plants of sugar beet will adjust nutrient conservation strategies to balance the altered elemental stoichiometric homeostasis (C:N:P) and dry matter production accordingly to $\mathrm{NH}_{4}{ }^{+}$concentrations in presence of $\mathrm{Si}$. While with absence of $\mathrm{Si}$ in the nutrient solution may exacerbate $\mathrm{NH}_{4}{ }^{+}$toxicity due to disturbance in elementary stoichiometric ratios. Thus, the aim of this study was to evaluate the combined and isolated effects of different $\mathrm{NH}_{4}{ }^{+}$concentration in presence or absence of Si on C:N:P stoichiometry and yield of sugar beet.

\section{Materials And Methods}

\subsection{Installation and conduction of the experiment}

This study was performed out in a greenhouse at the Faculty of Agricultural and Veterinary Sciences (FCAV), UNESP Jaboticabal, SP, Brazil ( $21^{\circ} 15 \square 22^{\prime \prime}$ S and $\left.48^{\circ} 18 \square 58^{\prime \prime} \mathrm{W}\right)$, to evaluate the impact of silicon on C:N:P stoichiometry and yield parameters of sugar beet plants (Beta vulgaris L.) Cv. Early Wonder under different ammonium concentration. Plants were cultivated in controlled conditions in a plant growth chamber with a light/dark cycle of 13/11 h, temperature regime of $35 / 25{ }^{\circ} \mathrm{C}$, and relative humidity of approximately $50 \%$. Every experimental unit was composed of a plastic pot with a capacity of $3.8 \mathrm{~L}$, in which was a mixture of the coarse vermiculite substrate (90 to $100 \%$ of particles between 1.19 and 1.50 $\mathrm{mm}$ ) in a 1:1 proportion (v/v) with super fine particles (90 to $100 \%$ of particles between 0.21 and $0.33 \mathrm{~mm}$ ), to allow for adequate porosity and aeration (Sarasketa et al. 2014).

\subsection{Growth condition}

In each pot, 6 seeds were placed at a depth of $2 \mathrm{~cm}$, which were thinned 5 days after their emergence, leaving only 2 plants for every pot to allow for an adequate distance for root growth. Initially $100 \mathrm{ml}$ of distilled water per pot was used for the first 7 days, to maintain the required humidity of the seedlings. Distilled water was replaced by $200 \mathrm{ml}$ of nutritive solution for every pot (Hoagland and Arnon 1950), with modification in the source of iron alternating between Fe-EDTA and Fe-EDDHMA. The $\mathrm{pH}$ of nutrient solution was monitored daily and maintained at $5.4 \pm 0.3$ using $0.01 \mathrm{~mol} \mathrm{~L}^{-1}$ sodium hydroxide $(\mathrm{NaOH})$ and/or hydrochloric acid $(\mathrm{HCl})$.

\subsection{Experimental design}

The experimental design used was completely randomized, in a factorial scheme of $5 \times 2$, corresponding with five concentrations of $\mathrm{NH}_{4}{ }^{+}\left(1.0,7.5,15,22.5\right.$, and $\left.30 \mathrm{mmol} \mathrm{L}^{-1}\right)$ and the absence and presence of Si $\left(2 \mathrm{mmol} \mathrm{L}^{-1}\right)$, with four replicates. Two $\mathrm{mmol} \mathrm{L}^{-1} \mathrm{Si}$ concentration used here was based on the experiments carried out by our research group (GENPLANT) $5,9,11$ and the fact that the solubility of monosilicic acid $\left(\mathrm{H}_{4} \mathrm{SiO}_{4}\right)$ in nutrient solution is close to this concentration ${ }^{30}$. The source of $\mathrm{N}$ used was $\mathrm{NH}_{4} \mathrm{Cl}$, with $\mathrm{Si}$ in the form of $\mathrm{H}_{4} \mathrm{SiO}_{4}(\mathrm{Si}=28.5 \mathrm{~g}$ $\left.\mathrm{L}^{-1}\right)$.

\subsection{Determination of dry matter}

After harvest, all the plants were collected and washed with detergent solution $(0.2 \%)$, hydrochloric acid solution ( $0.1 \%)$, and finally deionized water. All plant material was placed in paper sacks and dried in a forced air circulation oven $\left(65 \pm 5^{\circ} \mathrm{C}\right)$ until they reached a constant weight, and then the total dry mass was measured on a digital precision scale. Later, it was pulverized in an electric grinder (Wiley). 


\subsection{Carbon, nitrogen, phosphorus, and silicon analysis}

For the nutrients $(\mathrm{N}, \mathrm{P}$, and $\mathrm{C})$ the material collected at every replication $(\mathrm{n}=4)$ per pot was mixed to form a composite sample. Using the powdered plant material, we measured the total $\mathrm{C}$, and $\mathrm{N}$ concentration in shoots and root using the method of dry combustion (at $1000{ }^{\circ} \mathrm{C}$ ) in an elemental analyzer (LECO Truspec CHNS) calibrated with the pattern LECO 502-278 of wheat $(C=45.00 \%$ and $N=2.68 \%)$. Si concentration was determined according to (Korndörfer et al., 2004), meanwhile, the P concentration (of acid digests) was measured by spectrophotometer (model SP-1105) using the molybdenum antimony colorimetric method and $\mathrm{N}$ following the methods described by Bataglia et al. (1983). Using the C, N, and P concentrations in different plant organs, we calculated the C:P, C:N, and N:P ratios ${ }^{29}$.

\subsection{Statistical analysis}

Data were subjected to a two-way analysis of variance (ANOVA) after checking the homogeneity of variance of Levene, F test. The Shapiro-Wilks W test was used to test the normality of the data. The mean values were compared using Tukey's test $(\mathrm{p}<0.05)$. In this study, we tested the main effects of five ammonium concentrations $\left(\mathrm{NH}_{4}{ }^{+}\right)$in absence and presence of Silicon (Si), as well as their interactions $(\mathrm{Si} \times \mathrm{N})$. All analyses were performed using the statistical software Agroestat ${ }^{31}$.

\section{Results}

Our data revealed interactive effects between $\mathrm{N} \times \mathrm{Si}$ for $\mathrm{C}$ concentration [C], $\mathrm{N}$ concentration [N], $\mathrm{P}$ concentration [P], and Si concentration [Si] in shoots (Fig. 1a-d). While [C] remained stable for the shoots of $B$. vulgaris, in the presence of $\mathrm{Si}$, the $[\mathrm{N}]$ increased, reaching its highest value in the concentration of 15 $\mathrm{mmol} \mathrm{L}^{-1}$ in the presence of silicon, showing significant differences between the treatments (Fig.1a-b). Similarly, to the [N], was observed for [P] and [Si] in the shoots (Fig. 1c-d). The concentrations of P increased in the presence of Si up to a concentration of $15 \mathrm{mmol} \mathrm{L}^{-1}$ of $\mathrm{NH}_{4}{ }^{+}$and after they decreased, but without significant differences in relation to the same concentrations in the absence of Si.

The ANOVA revealed a significant interaction between [Si] and $[\mathrm{N}](\mathrm{Si} \times \mathrm{N})$ in the roots of sugar beet plants depending on the treatment. In the absence of $\mathrm{Si}$, the [C] decreases linearly as $\mathrm{NH}_{4}{ }^{+}$concentration increased up to $30 \mathrm{mmol} \mathrm{L}^{-1} \mathrm{NH}_{4}{ }^{+}$. In an opposite direction, the presence of $\mathrm{Si}$ in the nutrient solution increases the [C] (Fig. 2a). On the other hand, an increase in the concentration of $\mathrm{NH}_{4}{ }^{+}$decreased [N], especially in the plants cultivated without the incorporation of $\mathrm{Si}$ in the nutritive solution in the last $\mathrm{NH}_{4}{ }^{+}$concentration (Fig. 2b). Both [P] and [Si] in root increased in the presence of Si in the nutrient

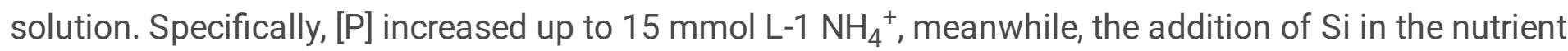
solution resulted in higher levels of $\mathrm{Si}$ in the root of the sugar beet, relative to plants without $\mathrm{Si}$ supplementation, across in all concentrations of $\mathrm{NH}_{4}{ }^{+}$(Figure 2c-d).

Shoot $\mathrm{C}: \mathrm{N}$ ratio increased in absence of $\mathrm{Si}$, however, an interactive effect between $\mathrm{Si} \times \mathrm{N}$ decreased $\mathrm{C}: \mathrm{N}$ ratio in the presence of Si for all $\mathrm{NH}_{4}{ }^{+}$concentrations (Fig. 3a). Shoot C:P ratio show an interaction $\mathrm{Si} \times \mathrm{N}$ and increased under higher $\mathrm{NH}_{4}{ }^{+}$concentration conditions in the nutrient solution, independently of presence or absence of $\mathrm{Si}$ (Fig. 3b). The highest $\mathrm{N}$ : $\mathrm{P}$ ratio of the shoot was found in $15 \mathrm{mmol} \mathrm{L}^{-1} \mathrm{NH}_{4}^{+}$ concentration in the absence of $\mathrm{Si}$ (Fig 3c). Conversely, the $\mathrm{N}$ : P ratio increased with the higher $\mathrm{NH}_{4}{ }^{+}$ 
concentration in the presence of $\mathrm{Si}$ in the nutrient solution (Fig 3c). We found a growing increase in the dry matter production of the shoots up to the ammonium concentration of $15 \mathrm{mmol} \mathrm{L}^{-1}$ (Fig. 3d). From this concentration, the tendency was to gradually decrease, but it was always greater in the presence of $\mathrm{Si}$, when compared to plants without the addition of Si. Shoot dry matter was significantly influenced by the interactive effects between $\mathrm{Si} \times \mathrm{N}$.

Root C:N, C:P, and N:P ratios were significantly influenced by the interactive effects of silicon and ammonium (Fig. 4a-c). In comparison with the plants that growing in the presence of $\mathrm{Si}$, the concentration of $15 \mathrm{mml} \mathrm{NH}_{4}{ }^{+}$had a significant positive effect on the $\mathrm{C}: \mathrm{N}$ ratio of the roots in the absence of $\mathrm{Si}$, while the opposite effect was observed at a higher concentration of $22.5 \mathrm{mmol} \mathrm{NH}_{4}{ }^{+}(\mathrm{Fig}$. 4a). C:P ratio decreased in plants supplied with $\mathrm{Si}$ under the first three concentrations of $\mathrm{NH}_{4}{ }^{+}$(from 1 mmol $\mathrm{L}^{-1}$ to $15 \mathrm{mmol} \mathrm{L}^{-1}$ ) in the nutrient solution (Fig. 4b). However, Si increased C:P ratio under last two concentrations of $\mathrm{NH}_{4}{ }^{+}$(from $22.5 \mathrm{mmol} \mathrm{L}^{-1}$ to $30 \mathrm{mmol} \mathrm{L}^{-1}$ ) in the nutrient solution. Except for the first and last concentration of $\mathrm{NH}_{4}{ }^{+}$in the nutrient solution, $\mathrm{C}: \mathrm{N}$ ratio in the root increased significantly in plants in the absence of silicon (Fig 4c). In contrast, root dry matter increased for all treatment in the presence of $\mathrm{Si}$, regardless of the concentration of $\mathrm{NH}_{4}{ }^{+}$in the nutrient solution, compared with plants the absence of silicon (Fig. 4d).

\section{Discussion}

The use of $\mathrm{N}$ supply based on the $\mathrm{NH}_{4}{ }^{+}$form is used in cheap fertilizers as urea, the use of which can reduce the costs of production and increases farmers' incomes ${ }^{1}$. Unlike $\mathrm{NO}_{3}{ }^{-}, \mathrm{NH}_{4}{ }^{+}$is directly incorporated into organic compounds without the need for energy-dependent enzymatic reduction ${ }^{4}$. Consequently, the lower metabolic energy expenditure associated with ammoniacal nutrition can be converted into higher plant growth, and thus higher production. However, despite its value as a fertilizer, it is well established that an excess of $\mathrm{NH}_{4}{ }^{+}$can promote the production of reactive oxygen species (ROS), which can cause reductions in cytoplasmic $\mathrm{pH}$, photosynthetic rate, transpiration, and stomatal conductance $1,5,32$. In addition, an excess $\mathrm{NH}_{4}{ }^{+}$can inhibit root growth, and subsequently vegetative shoot growth and yield ${ }^{33}$.

Several experiments have focused on the relationships between nutrient stoichiometry in plant communities and geographical variations or climatic factors $28,29,34$. However, to the best of our knowledge, few studies have focused on the effects of $\mathrm{NH}_{4}{ }^{+}$toxicity on $\mathrm{C}: \mathrm{N}: \mathrm{P}$ ratio in horticultural crops.

A strategy that has proven its effectiveness in mitigating the damages caused by excess of $\mathrm{NH}_{4}{ }^{+}$is the use of $\mathrm{Si}$. Although $\mathrm{Si}$ is not an essential nutrient, its application is beneficial. Si application can mitigate the harmful effects of oxidative stress in the photosynthetic apparatus of different crops ${ }^{1,5}$, improve antioxidant responses ${ }^{22}$, increasing dry matter by enhancing ionic homeostasis in roots and shoots of different plant species ${ }^{35}$. The addition of Si induces changes in the $\mathrm{C}: \mathrm{N}: \mathrm{P}$ stoichiometry and enhances 
stoichiometric homeostasis of sorghum and sunflower plants under salt stress ${ }^{34}$. However, the patterns of plant C:N:P stoichiometry are species-specific and dependent of various factors and ambient conditions ${ }^{29,36}$.

Plant exposed to high concentrations of $\mathrm{NH}_{4}{ }^{+}$typically show symptoms of $\mathrm{NH}_{4}{ }^{+}$toxicity. At low concentrations $\left(<3 \mathrm{mmol} \mathrm{L}^{-1}\right), \mathrm{NH}_{4}{ }^{+}$is typically the $\mathrm{N}$ source preferred by plants, but above a certain threshold e.g., $15 \mathrm{mmol} \mathrm{L}^{-1}$ in sugar beet, $30 \mathrm{mmol} \mathrm{L}^{-1}$ in radish, $\mathrm{NH}_{4}{ }^{+}$becomes toxic ${ }^{1,5}$. This threshold depends on plant species and on variety or cultivars of the same species ${ }^{1,5,37}$. Recently, (Olivera-Viciedo et al., 2020) reported that a concentration of $30 \mathrm{mmol} \mathrm{L}^{-1}, \mathrm{NH}_{4}{ }^{+}$was shown to have negative effects on the total dry biomass, photosynthesis, transpiration, and stomatal conductance of radish seedlings, even in the presence of $\mathrm{Si}$ in the nutrient solution, whereas instantaneous water-use efficiency and the green color index increased in the presence of $\mathrm{Si}$.

In this study, was observed that the highest levels of $\mathrm{NH}_{4}{ }^{+}$affected stoichiometric homeostasis and reduced the dry matter by decreased the shoots and roots $[\mathrm{N}]$ and $[\mathrm{P}]$, especially in the plants cultivated without $\mathrm{Si}$ in the nutritive solution corroborating our main hypothesis. These findings indicate that application of $\mathrm{Si}$ to the nutrient solution used in hydroponic cultivation could provide an effective means of alleviating the unfavorable effects induced by $\mathrm{NH}_{4}{ }^{+}$toxicity in agreement with ours previous experiment ${ }^{1,5}$. Although plants are able to survive with very low $\mathrm{Si}$ availability under greenhouse or some controlled laboratory conditions, several studies have shown that plants fertilized with Si increase photosynthesis, water use efficiency, and consequently have higher biomass production compared with non-Si-fertilized plants ${ }^{1,5,11,22}$.

Higher dry matter of shoots and roots (Fig 3d, and Fig 4d) in the presence of Si may be given by a higher $[\mathrm{N}]$ and $[\mathrm{P}]$ in both plant-organs (Fig 1b, $\mathrm{C} ;$ Fig $2 \mathrm{~b}, \mathrm{c}$ ). However, it should be noted that there was a more severe effect of $\mathrm{NH}_{4}{ }^{+}$toxicity in the roots than shoot when $\mathrm{NH}_{4}{ }^{+}$concentrations were higher than 15 mmol L-1 , probably because roots constitute the first $\mathrm{NH}_{4}{ }^{+}$sensor, and the initial signals of $\mathrm{NH}_{4}{ }^{+}$toxicity appear at root level with a severe modification of the root architecture that result in a decreases root/shoot ratio, as reported in previous studies ${ }^{4,38}$. Therefore, it was concluded that the role of $\mathrm{Si}$ on $\mathrm{C}: \mathrm{N}: \mathrm{P}$ stoichiometry and dry matter production of sugar beet could be related to growth conditions, $\mathrm{NH}_{4}{ }^{+}$ concentrations, and the ability of plants to maintain a relatively stable composition of nutrients $(C, N, P)$, and remain in homeostasis.

\section{Declarations}

\section{Conflicts of Interest}

The authors declare that they have no conflicts of interest 


\section{References}

1 Olivera-Viciedo D, Mello Prado R, Lizcano Toledo R, Salas Aguilar D, Claudio Nascimento dos Santos L, Calero Hurtado A, Peña Calzada K, and Betancourt Aguilar C. Physiological role of silicon in radish seedlings under ammonium toxicity. J Sci Food Agric:jsfa.10587 (2020).

2 Prado R de M. Introduction to Plant Nutrition. Miner Nutr Trop plants Springer, Cham; :1-38 (2021).

3 Hachiya T and Noguchi K. Integrative response of plant mitochondrial electron transport chain to nitrogen source. Plant Cell Rep Springer; 30:195-204 (2011).

4 Bittsánszky A, Pilinszky K, Gyulai G, and Komives T. Overcoming ammonium toxicity. Plant Sci Elsevier Ireland Ltd; 231:184-190 (2015).

5 Olivera-Viciedo D, Mello Prado R de, Lizcano Toledo R, Santos LCN dos, Calero Hurtado A, Nedd LLT, and Castellanos Gonzalez L. Silicon Supplementation Alleviates Ammonium Toxicity in Sugar Beet (Beta vulgaris L.). J Soil Sci Plant Nutr Springer; 19:413-419 (2019).

6 Domínguez-Valdivia MD, Aparicio-Tejo PM, Lamsfus C, Cruz C, Martins-Loução MA, and Moran JF. Nitrogen nutrition and antioxidant metabolism in ammonium-tolerant and -sensitive plants. Physiol Plant John Wiley \& Sons, Ltd; 132:359-369 (2008).

$7 \quad$ Hirel B, Gouis J Le, Ney B, and Gallais A. The challenge of improving nitrogen use efficiency in crop plants: Towards a more central role for genetic variability and quantitative genetics within integrated approaches. Journal of Experimental Botany Oxford Academic; p. 2369-2387 2007.

8 Pavlovic J, Kostic L, Bosnic P, Kirkby EA, and Nikolic M. Interactions of Silicon With Essential and Beneficial Elements in Plants. Front Plant Sci Frontiers; 0:1224 (2021).

9 Epstein E. The anomaly of silicon in plant biology. Proc. Natl. Acad. Sci. U. S. A. National Academy of Sciences; p. 11-17 1994.

10 Yan G chao, Nikolic M, Ye M jun, Xiao Z xi, and Liang Y chao. Silicon acquisition and accumulation in plant and its significance for agriculture. J Integr Agric Elsevier; 17:2138-2150 (2018).

11 Bakhat HF, Bibi N, Zia Z, Abbas S, Hammad HM, Fahad S, Ashraf MR, Shah GM, Rabbani F, and Saeed S. Silicon mitigates biotic stresses in crop plants: A review. Crop Prot Elsevier; 104:21-34 (2018).

12 Rocha JR, Mello Prado R de, and Cássia Piccolo M de. New outcomes on how silicon enables the cultivation of Panicum maximum in soil with water restriction. Sci Reports 2022121 Nature Publishing Group; 12:1-13 (2022). 
13 Guntzer F, Keller C, and Meunier J-D. Benefits of plant silicon for crops: a review. Agron Sustain Dev 2011321 Springer; 32:201-213 (2011).

14 Frew A, Weston LA, Reynolds OL, and Gurr GM. The role of silicon in plant biology: a paradigm shift in research approach. Ann Bot Oxford Academic; 121:1265-1273 (2018).

15 Camargo MS de, Bezerra BKL, Vitti AC, Silva MA, and Oliveira A. Silicon fertilization reduces the deleterious effects of water deficit in sugarcane. $J$ soil Sci plant Nutr Chilean Society of Soil Science; 17:99-111 (2017).

16 Olivera-Viciedo D, Mello Prado R de, Lizcano Toledo R, Nascimento dos Santos LC, and Peña Calzada K. Respuesta de las plántulas del rábano (Raphanus sativus L.) a diferentes concentraciones de nitrógeno amoniacal en ausencia y presencia de silicio. Agron Colomb Universidad Nacional de Colombia1; 35:198-204 (2017).

17 Gou T, Yang L, Hu W, Chen X, Zhu Y, Guo J, and Gong H. Silicon improves the growth of cucumber under excess nitrate stress by enhancing nitrogen assimilation and chlorophyll synthesis. Plant Physiol Biochem Elsevier Masson; 152:53-61 (2020).

18 Prado R de M. Introduction to Plant Nutrition. Miner. Nutr. Trop. plants. Springer, Cham; 2021.

19 Teixeira GCM, Prado R de M, Rocha AMS, and Piccolo M de C. Root- and foliar-applied silicon modifies $\mathrm{C}$ : N: $\mathrm{P}$ ratio and increases the nutritional efficiency of pre-sprouted sugarcane seedlings under water deficit. PLoS One Public Library of Science; 15:e0240847 (2020).

20 Schaller J, Brackhage C, Gessner MO, Bäuker E, and Dudel EG. Silicon supply modifies C:N:P stoichiometry and growth of Phragmites australis. Plant Biol John Wiley \& Sons, Ltd; 14:392-396 (2012).

21 Calero-Hurtado A, Aparecida Chiconato D, Mello Prado R de, Silveira Sousa Junior G da, and Felisberto G. Silicon attenuates sodium toxicity by improving nutritional efficiency in sorghum and sunflower plants. Plant Physiol Biochem Elsevier Masson SAS; 142:224-233 (2019).

22 Calero-Hurtado A, Chiconato DA, Prado R de M, Sousa Junior G da S, Gratão PL, Felisberto G, Olivera Viciedo D, and Mathias dos Santos DM. Different methods of silicon application attenuate salt stress in sorghum and sunflower by modifying the antioxidative defense mechanism. Ecotoxicol Environ Saf 203:110964 (2020).

23 Lucchi C De, Biancardi E, Skaracis G, Biaggi M De, Pavli O, Ravi S, Chiodi C, Broccanello C, and Stevanato P. Sugar Beet (Beta vulgaris ssp. vulgaris L.) Improvement with Next-Generation Breeding Technology. Adv Plant Breed Strateg Veg Crop Springer, Cham; :305-343 (2021).

24 Souza R, Fontanetti A, Fiorini C, and Almeida K. Cultura da beterraba: Cultivo convencional e cultivo orgânico. 2003. 
25 Sinta Z and Garo G. Influence of Plant Density and Nitrogen Fertilizer Rates on Yield and Yield Components of Beetroot (Beta vulgaris L.). Serrano M, ed. Int J Agron 2021:1-7 (2021).

26 Sterner RW and Elser JJ. Ecological stoichiometry: the biology of elements from molecules to the biosphere. Princeton University Press; 2002.

27 Elser JJ, Fagan WF, Kerkhoff AJ, Swenson NG, and Enquist BJ. Biological stoichiometry of plant production: metabolism, scaling and ecological response to global change. New Phyto/ 186:593-608 (2010).

28 Olivera-Viciedo D, Mello Prado R de, Martínez CA, Habermann E, and Cássia Piccolo M de. Shortterm warming and water stress affect Panicum maximum Jacq. stoichiometric homeostasis and biomass production. Sci Total Environ 681:267-274 (2019).

29 Olivera-Viciedo D, Mello Prado R de, Martinez CA, Habermann E, Cássia Piccolo M de, Calero Hurtado A, Barreto RF, and Peña Calzada K. Changes in soil water availability and air-temperature impact biomass allocation and C:N:P stoichiometry in different organs of Stylosanthes capitata Vogel. J Environ Manage 278 (2021).

30 Gao X, Zou C, Wang L, and Zhang F. Silicon Improves Water Use Efficiency in Maize Plants. J Plant Nutr Taylor \& Francis Group ; 27:1457-1470 (2005).

31 Barbosa J and Maldonado J. Experimentação agronômica e AgroEstat: sistema para análises estatísticas de ensaios agronômicos. Jaboticabal: Departamento de Ciências Exatas-Universidade Estadual Paulista (UNESP); 2015.

32 Hu L, Yu J, Liao W, Zhang G, Xie J, Lv J, Xiao X, Yang B, Zhou R, and Bu R. Moderate ammonium: Nitrate alleviates low light intensity stress in mini Chinese cabbage seedling by regulating root architecture and photosynthesis. Sci Hortic (Amsterdam) Elsevier; 186:143-153 (2015).

33 Di DW, Sun L, Zhang X, Li G, Kronzucker HJ, and Shi W. Involvement of auxin in the regulation of ammonium tolerance in rice (Oryza sativa L.). Plant Soil Springer International Publishing; 432:373-387 (2018).

34 Calero-Hurtado A, Chiconato DA, Prado R de M, Sousa Junior G da S, Olivera Viciedo D, and Piccolo $\mathrm{M}$ de C. Silicon application induces changes C:N:P stoichiometry and enhances stoichiometric homeostasis of sorghum and sunflower plants under salt stress. Saudi J Biol Sci 27:3711-3719 (2020).

35 Calero-Hurtado A, Chiconato DA, Mello Prado R de, Silveira Sousa Junior G da, Viciedo DO, Díaz YP, Calzada KP, and Gratão PL. Silicon Alleviates Sodium Toxicity in Sorghum and Sunflower Plants by Enhancing lonic Homeostasis in Roots and Shoots and Increasing Dry Matter Accumulation. Silicon Springer; 13:475-486 (2021). 
and $\mathrm{P}$ conservation strategies of a desert steppe species Glycyrrhiza uralensis. Sci Rep Nature Publishing Group; 8:12668 (2018).

37 Cruz C, Domínguez-Valdivia MD, Aparicio-Tejo PM, Lamsfus C, Bio A, Martins-Loução MA, and Moran JF. Intra-specific variation in pea responses to ammonium nutrition leads to different degrees of tolerance. Environ Exp Bot Elsevier; 70:233-243 (2011).

38 Esteban R, Ariz I, Cruz C, and Moran JF. Review: Mechanisms of ammonium toxicity and the quest for tolerance. Plant Sci Elsevier Ireland Ltd; 248:92-101 (2016).

\section{Figures}

\section{Figure 1}

Effects of $\mathrm{NH}_{4}{ }^{+}$concentrations, in the presence (+Si) and absence of $\mathrm{Si}(-\mathrm{Si})$ on shoot $\mathrm{C}$ concentration (a), shoot $\mathrm{N}$ concentration (b), shoot $\mathrm{P}$ concentration (c), and shoot $\mathrm{Si}$ concentration (d) of sugar beet plants. Different uppercase letters indicate significant differences between different $\mathrm{NH}_{4}{ }^{+}$concentration at the same Si concentration, while Different lowercase letters indicate significant differences between different Si concentration within the same $\mathrm{NH}_{4}{ }^{+}$concentration, according to the $\mathrm{F}$ test. Error bars show standard errors based on the average values of four replicates $(n=4)$. ${ }^{*} p \leq 0.05$; $* * p \leq 0.01$; ns, not significant; Si $\times$ $\mathrm{N}, \mathrm{Si}-\mathrm{NH}_{4}{ }^{+}$interaction.

\section{Figure 2}

Effects of $\mathrm{NH}_{4}{ }^{+}$concentrations, in the presence (+Si) and absence of $\mathrm{Si}(-\mathrm{Si})$ on root $\mathrm{C}$ concentration (a), root $\mathrm{N}$ concentration (b), root $\mathrm{P}$ concentration (c), and root $\mathrm{Si}$ concentration (d) of sugar beet plants. Different uppercase letters indicate significant differences between different $\mathrm{NH}_{4}{ }^{+}$concentration at the same Si concentration, while Different lowercase letters indicate significant differences between different Si concentration within the same $\mathrm{NH}_{4}{ }^{+}$concentration, according to the $\mathrm{F}$ test. Error bars show standard errors based on the average values of four replicates $(n=4) .{ }^{*} p \leq 0.05 ; * \star p \leq 0.01 ; \mathrm{Si} \times \mathrm{N}, \mathrm{Si}-\mathrm{NH}_{4}{ }^{+}$ interaction.

\section{Figure 3}


Effects of $\mathrm{NH}_{4}{ }^{+}$concentrations, in the presence (+Si) and absence of $\mathrm{Si}(-\mathrm{Si})$ on shoot C:N ratio (a), shoot C:P ratio (b), shoot N:P ratio (c), and shoot dry matter (d) of sugar beet plants. Different uppercase letters indicate significant differences between different $\mathrm{NH}_{4}{ }^{+}$concentration at the same $\mathrm{Si}$ concentration, while Different lowercase letters indicate significant differences between different Si concentration within the same $\mathrm{NH}_{4}{ }^{+}$concentration, according to the $\mathrm{F}$ test. Error bars show standard errors based on the average values of four replicates $(\mathrm{n}=4) .{ }^{*} p \leq 0.05 ;{ }^{*} p \leq 0.01 ; \mathrm{ns}$, not significant; $\mathrm{Si} \times \mathrm{N}, \mathrm{Si}-\mathrm{NH}_{4}{ }^{+}$interaction.

\section{Figure 4}

Effects of $\mathrm{NH}_{4}{ }^{+}$concentrations, in the presence $(+\mathrm{Si})$ and absence of $\mathrm{Si}(-\mathrm{Si})$ on root $\mathrm{C}: \mathrm{N}$ ratio (a), root C:P ratio (b), root N:P ratio (c), and root dry matter (d) of sugar beet plants. Different uppercase letters indicate significant differences between different $\mathrm{NH}_{4}{ }^{+}$concentration at the same Si concentration, while Different lowercase letters indicate significant differences between different Si concentration within the same $\mathrm{NH}_{4}{ }^{+}$concentration, according to the $\mathrm{F}$ test. Error bars show standard errors based on the average values of four replicates $(\mathrm{n}=4) .{ }^{*} p \leq 0.05 ; * \star p \leq 0.01 ; \mathrm{ns}$, not significant; $\mathrm{Si} \times \mathrm{N}, \mathrm{Si}-\mathrm{NH}_{4}{ }^{+}$interaction. 